\title{
Penggunaan Pembelajaran Cooperative Script dalam Upaya Meningkatkan Hasil Belajar Siswa
}

\author{
Odih \\ Sekolah Dasar Negeri 013 Hulu Teso Kecamatan Logas Tanah Darat Kabupaten Kuantan Singingi, \\ Indonesia \\ e-mail: odihsdn013kuansing@gmail.com
}

\begin{abstract}
The aim of this research is to increase the achievement of students of grade 4 Elementary School 008 Sukaraja in the concept of multiplying numbers by using Cooperative Script learning. This study is a classroom action research. The subjects consist of a teacher and 12 students, 6 male students and 6 female students, who are enrolled in Elementary School 008 of Sukaraja, Logas Tanah Darat district of Kuantan Singingi regency year 2015/2016. The material being studied is Math, multiplication until 100. This research was done in two cycles. Each cycles being compared; the percentage of completion always increase. Before the cycle, 58\% students reaching the standard mastery, and it increased to $10 \%$ in cycle I. Moreover, students' average score, which was only 58.33 in the beginning of the cycles, increased to 80.00 in cycle II. Thus, it can be concluded that the use of Cooperative Script method is able to increase the Math achievement of the grade 4 students of Elementary School 008 Sukaraja of Logas Tanah Datar district, Kuantan Singingi Regency, year 2015/2016.
\end{abstract}

Keywords: Cooperative Script Learning, Learning Achivement.

\section{PENDAHULUAN}

Kualitas kehidupan suatu bangsa sangat ditentukan oleh faktor pendidikan. Pedidikan yang diselenggarakan harus mampu mencetak sumber daya manusia yang lebih siap untuk terjun dan berperan aktif dalam kehidupan nyata. Konkretnya pendidikan harus mampu menyiapkan tenaga-tenaga terampil yang mampu melayani dirinya sendiri dan orang lain serta dapat mengisi dan berperan aktif di berbagai sendi kehidupan kompetitif.

Mencetak sumber daya manusia yang lebih siap untuk terjun dan berperan aktif dalam kehidupan merupakan tanggungjawab guru sehingga guru merupakan pihak yang paling bertanggungjawab atas berhasilnya proses pembelajaran yang dilakukan di kelas. Belajar Menurut Sardiman (2007: 22) adalah sebagai suatu proses interaksi antara diri manusia dengan lingkungannya. Sedangkan menurut Djamarah (2006: 10) belajar adalah proses perubahan perilaku berkat pengalaman dan latihan dan dalam proses pembelajaran guru berkewajiban mempersiapkan rencana pembelajaran sera metode pembelajaran, alat peraga, buku-buku penunjang lainnya dan alat evaluasi.

Berdasarkan pengamatan di SD Negeri 008 Sukaraja Kecamatan Logas Tanah Darat Kabupaten Kuantan Singingi kelas IV dalam proses pembelajaran matematika, guru dalam menyampaikan materi matematika masih menekankan pada konsep yang terdapat dalam buku. Sebenarnya cara penyampaian guru yang cenderung tidak melibatkan siswa secara aktif dalam proses pembelajaran dan akan membawa pelajaran pada kondisi yang membosankan dan tidak merangsang pola fikir siswa. Salah satu konsep yang diajarkan berkelanjutan cenderung diberikan secara konseptual belaka adalah konsep tentang perkalian bilangan sampai seratus. 
Materi perkalian bilangan sampai seratus bukanlah mteri yang sukar tetapi menjadi tidak mudah apabila ketika diberikan secara langsung kepada siswa dengan cara penyampaian secara konseptual saja atau dengan menggunakan metode ceramah. Ini terlihat dari hasil belajar siswa, dari beberapa kali tes yang diberikan kepada siswa dari 5 soal tes yang diberikan hanya 3 orang siswa atau sekitar 12\% siswa dari 12 siswa yang dapat menjawab melebihi KKM.

Berdasarkan masalah di atas guru sebaiknya menggunakan pembelajaran cooperative script. Pembelajaran Cooperative Script adalah metode belajar dimana siswa bekerja berpasangan dan bergantian secara lisan mengikhtiarkan bagian-bagian dari materi yang dipelajari.. Adapun langkah-langkah pembelajaran cooperative script adalah sebagai berikut: 1 . Guru membagi siswa untuk berpasangan, 2. Guru mebagikan wacana atau materi tiap siswa untuk dibaca dan membuat ringkasan, 3.Guru dan siswa menetapkan siapa yang berperan sebagai pembicara dan siapa yang berperan sebagai pendengar, 4. Pembicara membacakan ringkasannya selengkap mungkin, 5. Bertukar peran, semula yang sebagai pembicara ditukar menjadi pendengar dan sebaliknya, 6. Kesimpulan siswa bersama-sama dengan guru dan 7. Penutup.

Berdasarkan hal tersebut maka perlu adanya usaha untuk menimbulkan keaktifan dengan mengadakan komunikasi yaitu guru dengan siswa dan siswa dengan rekannya. Salah satu pembelajaran yang ditawarkan adalah cooperative script. Penggunaan metode ini diharapakan dapat meningkatkan hasil belajar siswa pada pelajaran matematika khususnya pada materi perkalian bilangan sampai seratus.

\section{METODOLOGI}

Jenis penelitian ini adalah penelitian tindakan kelas, subjek dalam penelitian tindakan kelas ini adalah siswa kelas IV SD Negeri 008 Sukaraja Kecamatan Logas Tanah Darat Kabupaten Kuantan Singingi yang terdiri dari 6 orang siswa laki-laki dan 6 orang siswa perempuan pada semester ganjil tahun pelajaran 2015/2016. Mata pelajaran yang menjadi bahan penelitian adalah mata pelajaran Matematika materi perkalian bilangan sampai dengan 100. Pemikiran lemahnya kemampuan siswa terhadap perkalian bilanagan sampai 100 agar naik kekelas V. Kemudian teknik analsisi data yang digunakan lenbar observasi hasil belajar siswa dan daya serap siswa.

Pada penelitian perbaikan pembelajaran matematika ini dilakukan siklus I dan siklus II yaitu: (1) Rencana; (2) Pelaksanaan; (3) Pengamatan; (4) Refleksi.

\section{HASIL PENELITIAN DAN PEMBAHASAN}

\section{Hasil Belajar Siswa}

Tabel 1. Daftar Nilai Siswa pada Siklus I dan Siklus II

\begin{tabular}{cccc}
\hline \multirow{2}{*}{ No. Absen Siswa } & \multicolumn{2}{c}{ Hasil/Temuan } & Rata-Rata Siklus \\
\cline { 2 - 3 } & Siklus I & Siklus II & 65 \\
\hline 1 & 50 & 80 & 70 \\
2 & 60 & 80 & 55 \\
3 & 50 & 60 & 70 \\
4 & 60 & 80 & 75 \\
5 & 70 & 80 & 85 \\
6 & 70 & 100 &
\end{tabular}




\begin{tabular}{cccc}
7 & 50 & 80 & 65 \\
8 & 60 & 60 & 60 \\
9 & 50 & 80 & 65 \\
10 & 70 & 80 & 75 \\
11 & 50 & 80 & 65 \\
12 & 60 & 100 & 80 \\
\hline Jumlah & $\mathbf{7 0 0}$ & $\mathbf{9 6 0}$ & $\mathbf{8 3 0}$ \\
Rata-Rata & $\mathbf{5 8 , 3 3}$ & $\mathbf{8 0 , 0 0}$ & $\mathbf{6 9 , 1 7}$ \\
Persentase (\%) & $\mathbf{5 8}$ & $\mathbf{8 0}$ & $\mathbf{6 9}$ \\
\hline
\end{tabular}

Dilihat pada perkembangan nilai diatas dapat dilihat perkembangan yang signifikan terhadap pelajaran matematikan materi perkalian dan pembagian bilangan sampai seratus dari siklus I sampai dengan siklus II sehingga dapat disimpulkan bahwa dengan menggunakan metode cooperatif script dapat meningkatkan hasil belajar siswa kelas IV SD Negeri 008 Sukaraja Kecamatan Logas Tanah Darat Kabupaten Kuantan Singingi tahun pelajaran 2015/2016.

\section{Daya Serap Siswa}

Tabel 2. Penguasaan Siswa Melalui Tes Dua Siklus Pelajaran Matematika

\begin{tabular}{ccccccc}
\hline \multirow{2}{*}{ No } & \multirow{2}{*}{ Rentang Nilai } & \multirow{2}{*}{ Kategori } & \multicolumn{2}{c}{ Siklus I } & \multicolumn{2}{c}{ Siklus II } \\
\cline { 3 - 7 } & & F & $\mathbf{\%}$ & $\mathbf{F}$ & $\mathbf{0}$ \\
\hline 1 & $90-100$ & Istimewa & 0 & 0 & 2 & 17 \\
2 & $80-89$ & Baik sekali & 0 & 0 & 8 & 67 \\
3 & $70-79$ & Baik & 3 & 25 & 0 & 0 \\
4 & $60-69$ & Cukup & 4 & 33 & 2 & 17 \\
5 & $50-59$ & Kurang & 5 & 42 & 0 & 0 \\
6 & $<50$ & Kurang sekali & 0 & 0 & 0 & 0 \\
\hline \multicolumn{3}{c}{ Jumlah } & $\mathbf{1 2}$ & $\mathbf{1 0 0}$ & $\mathbf{1 2}$ & $\mathbf{1 0 0}$ \\
\hline & Rata-Rata & \multicolumn{3}{c}{$\mathbf{5 8 , 3 3}$} & \multicolumn{2}{c}{$\mathbf{8 0 , 0 0}$} \\
Kategori & \multicolumn{3}{c}{ Kurang } & \multicolumn{2}{c}{ Amat Baik } \\
\hline
\end{tabular}

Berdasarkan tabel diatas dapat dilihat bahwa pada nilai pada siklus I tidak ada siswa yang mendapatkan nilai istimewa dan nilai amat baik, yang mendapatkan nilai baik hanya 3 siswa atau 25\%, yang mendapatkan nilai cukup ada 4 siswa atau $33 \%$ dan yang mendapatkan nilai kurang ada 5 siswa atau $42 \%$ dan yang mendapatkan nilai kurang sekali tidak ada.

Sedangkan pada siklus II ada 2 siswa yang mendapatkan nilai istimewa atau 17\%, 8 orang siswa atau $67 \%$ yang mendapatkan nilai amat baik, yang mendapatkan nilai baik tidak ada, yang mendapatkan nilai kategori cukup ada 2 orang siswa atau 17\%, kategori kurang dan kategori kurang sekali tidak ada siswa yang memperolehnya. Perolehan nilai pada siklus II ini terdapat kenaikan yang cukup signifikan dari perolehan nilai pada siklus I

Dari perolehan nilai rata-rata siswa dari siklus I dan siklus II juga mengalami kenaikan. Dimana pada siklus I nilai rata-rata siswa hanya 58,33 dan dan dikategorikan dalam kategori kurang, sedangkan pada siklus II nilai rata-rata siswa mengalami kenaikan menjadi menjadi 80,00 dan dikategorikan dalam kategori amat baik. 


\section{KESIMPULAN DAN SARAN}

\section{Kesimpulan}

- Dari analisis perbandingan dari setiap siklus persentase ketuntasan selalu meningkat. Berawal dari kegiatan pembelajaran prasiklus yang hanya 58\% siswa yang tuntas tetapi pada kegiatan siklus II pertemuan 2 sudah meningkat menjadi 10\% siswa yang tuntas. Dan rata-rata nilai siswa yang pada awal siklus hanya 58,33 dan pada siklus II pertemuan 2 yakni 80,00. Penggunaan metode cooperative cript dapat meningkatkan hasi belajar siswa kelas IV SD Negeri 008 Sukaraja Kecamatan Logas Tanah Darat Kabupaten Kuantan Singingi tahun pelajaran 2015/2016.

- Dengan keberhasilan yang diperoleh siswa pada siklus II maka dapat diketahui bahwa dengan penggunaan metode cooperative cript dapat meningkatkan hasi belajar siswa kelas IV SD Negeri 008 Sukaraja tentang perkalian bilangan.

\section{Saran}

- Setiap guru hendaknya berani mencoba menerapkan metode mengajar bervariasi dalam pembelajaran.

- Guru harus mampu memotivasi siswa dalam proses pembelajaran.

- Pihak terkait harus mendukung upaya guru dalam meningkatkan hasil belajar siswa.

\section{REFERENSI}

Carol, 1997, Proses Belajar Mengajar, Bandung: Rosdakarya.

Djamarah, 2006, Pembelajaran Terpadu, Jakarta: Fifa Mulia Sejahtera.

Muktar, 2003, Metode Kooperatif Script, Jakarta: Fifa Mulia Sejahtera.

Nurhadi dan Senduk, 2003, Model-Model Pembelajaran Matematika, Jakarta.

Sardiman, 2007, Perencanaan Pembelajaran, Bandung: Rosdakarya.

Sudjana, 2004, Pengertian Belajar, Bandung: Rosdakarya. 